\title{
Release of Wall-bound Invertase and Trehalase in Neurospora crassa by Hydrolytic Enzymes
}

\author{
By PATRICIA L. Y. CHANG* AND J. R. TREVITHICK \\ Department of Biochemistry, University of Western Ontario, London, Ontario, Canada
}

(Accepted for publication 17 September 1971)

\begin{abstract}
SUMMARY
About $25 \%$ of the total cellular invertase and trehalase activity were found in a purified Neurospora wall preparation. Attempts were made to dissociate these enzymes from the walls with chemical reagents and hydrolytic enzymes. A detergent (Triton $X$-100), a sulphydryl reducing agent ( $\beta$-mercaptoethanol), a chelating agent (ethylenediaminetetraacetate), a concentrated salt solution ( $\mathrm{I} \mathrm{M}-\mathrm{KCl}$ ), and buffers ranging in $\mathrm{pH}$ from 3 to $\mathrm{Io}$ did not release them significantly. Snail-gut juice released more than $90 \%$ of both enzymes. $\beta$-I,3-Glucanase, prepared from Bacillus circulans WL-I2, also released similar amounts. Chitinase released about $80 \%$ of invertase and $60 \%$ of trehalase. Cellulase did not release any significant amount of either enzyme. Trypsin released only a few per cent of invertase and severely inactivated trehalase. Thus it appears that these two wall-bound enzymes are released only when covalent bonds of the Neurospora wall constituents are disrupted.
\end{abstract}

\section{INTRODUCTION}

According to Pollock (1962), the locations of enzymes in micro-organisms such as bacteria can be grouped into three categories: intracellular (inside the cytoplasmic membrane), surface-bound (outside the cytoplasmic membrane but cell-bound), and extracellular (easily separated from the cells by mild procedures). Considerable confusion exists in their designation because the surface-bound enzymes have been variously referred to as mural enzymes (Eberhart \& Beck, 1970), exocellular enzymes (Weimberg \& Orton, I966), external enzymes (Lampen, Neumann, Gascon \& Montenecourt, 1967), exoenzymes (Eberhart, 196I) and extracellular enzymes (Matile, 1964). The last three terms have also been used interchangeably to delineate any enzyme occurring in the milieu exterior to the wall. For a clearer operational definition, we propose to restrict the use of 'extracellular' to describe only the enzymes that are free in the medium or are easily separated from the cells by processes such as centrifugation or washing with water. Enzymes that are liberated on destruction of walls, e.g. during sphaeroplast formation, and whose activities are governed by factors in the medium, such as $\mathrm{pH}$ and the presence of substrates or inhibitors that do not penetrate the cell membrane, will be specifically described as 'cell-bound' or 'surface-bound' exoenzymes, or 'mural' exoenzymes (Trevithick \& Metzenberg, 1966) if they are exclusively found in the wall fraction. 'Exoenzymes' will refer generally to all the enzymes outside the permeability barrier (i.e. plasma membrane), regardless of whether they are still cell-bound or truly extracellular.

Many cell-bound exoenzymes have been identified in bacteria (Pollock, I962; Malamy \& Horecker, 1964; Coles \& Gross, 1967) and fungi (Mandels, I953; Matile, I964; Lampen, 1968; Eberhart \& Beck, 1970; Scott \& Metzenberg, 1970). Those that have been localized in the fungal wall fraction, i.e. mural exoenzymes, include trehalase (Hill \& Sussman, 1964),

* Present address: Biology Department, University of Waterloo, Waterloo, Ontario, Canada. 
invertase (Chung \& Trevithick, I970), $\alpha$-amylase (Tonomura \& Tanabe, I964), autolytic glucanase(s) and protease(s) (Mitchell \& Sabar, 1966; Mahadevan \& Mahadkar, 1970), laminarinase (Mahadevan \& Menon, I968), chitin synthetase (McMurrough \& BartnickiGarcia, 1970), and aryl- $\beta$-glucosidase (Eberhart \& Beck, I970; P. L. Y. Chang \& J. R. Trevithick, unpublished data).

In our laboratory about $25 \%$ of the total mycelial activities of invertase (EC. 3.2. I.26, $\beta$-D-fructofuranoside fructohydrolase) and trehalase (EC. 3.2 I I.28, $\alpha, \alpha^{\prime}$-glucoside I-glucohydrolase) were found in the purified wall fraction of Neurospora in the post-log phase of growth. Consequently, it was of interest to investigate the forces keeping these enzymes in their mural location. Attempts were made to dissociate these two enzymes from the wall fraction with a variety of chemical reagents and hydrolytic enzymes. The chemical reagents chosen were known to affect specific types of binding force, such as hydrogen bonding, hydrophobic bonding, salt linkage, or metal-ligand co-ordination bonding. Each hydrolytic enzyme used was known to hydrolyse a specific component of the Neurospora wall, i.e. protein, chitin, and glucan [mostly in $\beta$-I,3-glycosidic linkages with some $\beta$-I,4- and $\alpha$-I,4linkages (de Terra \& Tatum, I963; Mahadevan \& Tatum, 1965; Galsworthy, I966; Burnett, I968)].

\section{METHODS}

Organisms. Wild-type Neurospora crassa containing the Emerson genetic background was grown in Erlenmeyer flasks containing Fries minimal medium (Beadle \& Tatum, 1945), $2.7 \%$ (w/v) galactose, and $0.04 \mathrm{M}$-sodium succinate buffer ( $\mathrm{pH} 5.2$ ) for $20 \mathrm{~h}$ at $30^{\circ}$ in a gyratory shaker bath (New Brunswick Scientific Co., New Brunswick, New Jersey, U.S.A.) agitated at $\mathrm{I} 80 \mathrm{rev} . / \mathrm{min}$. The mycelium was harvested by filtration on a Millipore filter and used for preparation of the wall fraction.

Preparation of wall fraction. The procedure was modified from the method of Chung \& Trevithick (1970). Each batch of about I g mycelium (blotted dry with filter paper) was suspended in $20 \mathrm{ml}$ cold phosphate buffered saline (PBS: $0.9 \%$ sodium chloride in $0.0 \mathrm{I} \mathrm{M}$ sodium phosphate buffer at $\mathrm{pH}_{7 \cdot \mathrm{I}}$ ) in a metal container and disrupted with a sonifier (Branson Soni Power S I25) at maximum output for a period of 3 to $25 \mathrm{~min}$. More than $95 \%$ of the cells were estimated by phase-contrast microscopy to have been broken. The sample was kept below $10^{\circ}$ during this treatment by using an ethylene glycol-dry ice bath and turning on the sonifier intermittently. The suspension was centrifuged at $650 \mathrm{~g}$ in a model PR-2 Centrifuge (International Equipment Co., Needham Hts, Massachusetts, U.S.A.) at $4^{\circ}$ for $30 \mathrm{~min}$. The residue was washed successively with PBS, I \% (v/v) Triton X-Ioo, $\mathrm{M}-\mathrm{NaCl}$ (twice), PBS, and glass distilled water by centrifugation at $100 \mathrm{~g}$ for $\mathrm{I} 5 \mathrm{~min}$. The final wall residue was free from cytoplasmic debris when observed under the phase-contrast microscope, and contained less than $2 \%$ of the total cellular ribonucleic acid when measured by a modified Mejabaum reaction according to Merchant, Kahn \& Murphy (1964). The wall suspension used for all the following experiments had a dry wt of $\mathrm{I}$ to $\mathrm{I} \cdot 5 \mathrm{mg} / \mathrm{ml}$ and contained approximately 9 units of invertase activity and 0.03 units of trehalase activity per ml. (See below for definitions of units.)

\section{Treatment with chemical reagents}

(i) Buffers with a range of $\mathrm{pH}$ values from 3 to Io were prepared at a total final concentration of $0.14 \mathrm{M}$ : glycine-hydrochloric acid $\left(\mathrm{pH}_{3} \cdot 0\right)$; sodium acetate-acetic acid $\left(\mathrm{pH}_{4} \cdot 0\right.$, $\mathrm{pH} 5 \cdot 0)$; sodium monohydrogen phosphate-sodium dihydrogen phosphate $(\mathrm{pH} 6 \cdot 2, \mathrm{pH} 7 \cdot 0$, and $\mathrm{pH} 8 \cdot 0$ ); glycine-sodium hydroxide ( $\mathrm{pH} 9 \cdot 0, \mathrm{pH}$ I0॰0). 
For each buffer a wall suspension ( $\mathrm{I} \mathrm{ml}$ ) was mixed with the buffer solution $(0.5 \mathrm{ml})$ in a graduated centrifuge tube and kept at $23^{\circ}$ for $30 \mathrm{~min}$ with frequent agitation. The mixture was rapidly chilled in ice and immediately centrifuged for $20 \mathrm{~min}$ at $900 \mathrm{~g}$. The supernatant and the residual fractions were assayed for invertase and trehalase activities.

(ii) Triton X-IOO (octyl phenoxy polyethoxyethanol): a wall suspension was prepared omitting the Triton X-100 washing step in the routine procedure. It was mixed with an equal volume $(0.5 \mathrm{ml})$ of $2 \%(\mathrm{v} / \mathrm{v})$ Triton $\mathrm{X}-\mathrm{I} 00$ in a graduated centrifuge tube; after standing in an ice bath for $2 \mathrm{~h}$ the suspension was centrifuged at $650 \mathrm{~g}$ for $\mathrm{IO} \mathrm{min}$. The wall residue was washed with Io $\mathrm{ml}$ distilled water and made up to I $\mathrm{ml}$ with water.

Invertase activity of the wall residue and supernatant fractions was determined with and without the above Triton X-I0o treatment. No loss of invertase activity occurred in controls incubated under identical conditions.

(iii) EDTA (ethylenediaminetetraacetate): a sterilized 8-ml screw-cap vial containing EDTA (0. I M, I5 $\mu \mathrm{l}$ ), wall suspension $(2 \mathrm{ml})$, phosphate buffer $(0.6 \mathrm{M}, \mathrm{pH} 8,0.25 \mathrm{ml})$ and water $(0.74 \mathrm{ml})$ was agitated in a gyratory shaker bath at $30^{\circ}$ at $280 \mathrm{rev} . / \mathrm{min}$ for $4 \mathrm{~h}$, then centrifuged at $650 \mathrm{~g}$ for $\mathrm{I} 0 \mathrm{~min}$. Invertase activity in the supernatant and residual fractions was determined. Estimations from controls in which EDTA was replaced by water showed that about $5 \%$ of invertase activity was lost under the experimental conditions.

(iv) Potassium chloride: procedures were identical to those of EDTA treatment (iii). The incubation mixture consisted of $\mathrm{KCl}(4 \mathrm{M}, 0.75 \mathrm{ml})$, wall suspension $(2 \mathrm{ml})$ and phosphate buffer $(0.6 \mathrm{M}, \mathrm{pH} 8,0.25 \mathrm{ml})$. Only a negligible amount of invertase was inactivated by this treatment.

(v) $\beta$-Mercaptoethanol: procedures were identical to those of EDTA treatment (iii). The reaction mixture consisted of $\beta$-mercaptoethanol $(0.23 \mathrm{M}$ in $0.6 \mathrm{M}$-phosphate buffer at $\mathrm{pH} 8$, $0.25 \mathrm{ml})$, wall suspension $(2 \mathrm{ml})$ and water $(0.75 \mathrm{ml})$. About $15 \%$ of invertase activity was lost during this treatment.

\section{Hydrolytic enzymes}

The hydrolytic enzymes used were: snail-gut juice - Suc d'Helix pomatia (Industries Biologiques Françaises, Gennevilliers, France) processed according to the method of Trevithick \& Metzenberg (I964); trypsin (EC 3.4.4.4; Worthington Biochemical Corp., Freehold, New Jersey, U.S.A.) used as a $0 . \mathrm{I} \%$ solution in tris buffer $(0.125 \mathrm{M}, \mathrm{pH} 8 \cdot \mathrm{I})$

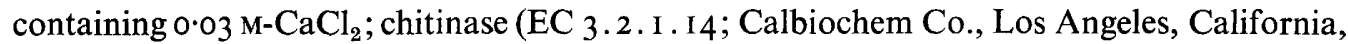
U.S.A.) used as a $0.2 \%$ solution in phosphate buffer (0.03 M, pH 6.3); cellulase (EC 3.2 . I . 4; CSEI, Worthington Biochemical Corp.) used as a $0.1 \%$ solution in sodium acetate buffer (0.02 $\mathrm{M}, \mathrm{pH} 5$ ); $\beta$-1,3-glucanase (EC 3.2 . I.6; prepared according to the method of Tanaka \& Phaff (1965) from the culture fluid of Bacillus circulans wL-I2, a stock culture of which was kindly supplied by Dr H. J. Phaff, University of California, Davis, California; purified Neurospora wall fraction was used as the carbon source instead of yeast wall). A unit of $\beta$-I,3-glucanase activity was defined as the amount of enzyme that liberated I $\mu$ mole of reducing sugar $/ \mathrm{min}$ at $\mathrm{pH} 5.8$ and $37^{\circ}$ from laminarin. The $\beta$-I,3-glucanase preparation used had a specific activity of $4.8 \mathrm{units} / \mathrm{mg}$ protein and a concentration of $0.35 \mathrm{mg}$ protein $/ \mathrm{ml}$ sodium succinate buffer (o.05 $\mathrm{M}, \mathrm{pH} 5.8)$.

\section{Substrate specificity of hydrolytic enzymes}

Snail-gut juice, glucanase preparations, and chitinase were tested for their glucanolytic specificities with laminarin (Pierce Chemical Co., Rockford, Illinois, U.S.A), pustulan (obtained through the courtesy of E. T. Reese, Quartermaster Research and Engineering 
Centre, Natick, Massachusetts, U.S.A.), sodium carboxymethyl cellulose (Hercules Incorp., Wilmington, Delaware) and soluble starch (Fisher Scientific Co., Don Mills, Ontario, Canada) according to the method of Tanaka \& Phaff (1965). The chitinolytic activity of these enzyme preparations was assayed according to the procedure in the Worthington Biochemical Enzyme Manual (Worthington Biochemical Corp.) with colloidal chitin prepared from poly- $N$-acetylglucosamine (Sigma Chemical Co., St Louis, Missouri, U.S.A.) according to the method of Berger \& Reynolds (1958). Trypsin, snail-gut juice and glucanase preparations were assayed for proteolytic activities according to the procedure of Drysdale \& Fling (1965).

\section{Digestion of Neurospora wall by hydrolytic enzymes}

A sterilized and stoppered Erlenmeyer flask $(25 \mathrm{ml})$ containing Io $\mathrm{ml}$ wall suspension, $5 \mathrm{ml}$ hydrolytic enzyme solution, and $50 \mu \mathrm{l}$ reconstituted penicillin-streptomycin mixture was incubated in a gyratory shaker bath at $30^{\circ}$ and $200 \mathrm{rev} . / \mathrm{min}$. Samples of I to $2 \mathrm{ml}$ were aseptically withdrawn at timed intervals with sterilized pipettes and centrifuged in graduated centrifuge tubes at $650 \mathrm{~g}$ for $10 \mathrm{~min}$ under refrigeration. Trehalase and invertase activities were measured in the supernatant and residual fractions.

In the digestion of wall fraction by $\beta$-I,3-glucanase, glucose was released from the wall polymers. This would have interfered with the trehalase and invertase assays which involved a determination of glucose as a hydrolytic product from their substrates (trehalose and sucrose respectively). Therefore the glucose in the digested wall samples was measured before the enzyme assays and subtracted from the total glucose detected after the enzyme assays to yield the experimental values.

Snail-gut juice and cellulase preparations, besides liberating glucose from walls, also had sucrose- and trehalose-cleaving activities. Therefore heat-inactivated ( $100^{\circ}$ for 5 to Io $\mathrm{min}$ ) wall suspensions were similarly incubated with these two enzyme preparations. 'Invertase' and 'trehalase' activities detected in this control were attributed to the snail-gut juice or cellulase preparations and subtracted from the gross activities obtained from the experimental samples.

\section{Preparation of ${ }^{14} \mathrm{C}$-labelled wall fraction}

A conidial suspension $(0 . \mathrm{I} \mathrm{ml}$, absorbance at $600 \mathrm{~nm}=20$ ) was inoculated into a $125 \mathrm{ml}$ Erlenmeyer flask containing $50 \mathrm{ml}$ Fries minimal medium, sodium succinate buffer $(0.04 \mathrm{M}$, $\mathrm{pH} 5.2)$, glucose $(0.5 \%)$ and $0.05 \mathrm{mCi}$-glucose $-{ }^{14} \mathrm{C}(\mathrm{U})$ with a specific activity of $2.8 \mathrm{mCi} /$ mM (Radiochemical Centre, Amersham, Buckinghamshire) for $24 \mathrm{~h}$ in a gyratory shaker bath at $30^{\circ}$ and $200 \mathrm{rev} . / \mathrm{min}$. The mycelium was harvested and ${ }^{14} \mathrm{C}$-labelled wall fractions prepared according to the procedure already described.

\section{Digestion of ${ }^{14} C$-labelled wall by hydrolytic enzymes}

${ }^{14} \mathrm{C}$-Labelled wall suspension $(0.6 \mathrm{ml})$ at a concentration of $\mathrm{I} \cdot \mathrm{I} \mathrm{mg}$ of dry wt and 29I,682 d.p.m. of radioactivity $/ \mathrm{ml}$ was added to $6 \mu \mathrm{l}$ reconstituted penicillin-streptomycin solution (BBL, Div. of BioQuest, Maryland, U.S.A.) and $0.3 \mathrm{ml}$ of a hydrolytic enzyme solution (snail-gut juice, trypsin, chitinase, cellulase, or $\beta$-I,3-glucanase) in a sterilized $8 \mathrm{ml}$ screwcap vial. After $24 \mathrm{~h}$ of incubation in a gyratory shaker bath at $30^{\circ}$ and $300 \mathrm{rev} . / \mathrm{min}$, IO0 $\mu \mathrm{l}$ and $200 \mu \mathrm{l}$ of the sample in each vial were withdrawn separately, spread evenly on glass-fibre filter paper, washed by filtration with $10 \mathrm{ml}$ and $20 \mathrm{ml}$ distilled water, and dried inside a counting vial for over $24 \mathrm{~h}$ at $80^{\circ}$. A toluene-based scintillation counting fluid (IO $\mathrm{ml}$ : containing $0 . \mathrm{I} \mathrm{g}$ I, 4-bis-2-(4-methyl-5-phenyloxazolyl)-benzene (POPOP) and $3 \mathrm{~g}$ 
2, 5-diphenyloxazole (PPO) per litre of toluene) was added to each vial and the radioactivity of the samples was measured with a Beckman LS-I50 Liquid Scintillation System.

\section{Enzyme assays}

For all enzyme assays, incubation mixtures containing wall residues were centrifuged at $6000 \mathrm{rev}$./ $\mathrm{min}$ for 5 to Io min with a GLC centrifuge (Sorvall) before the clear supernatant fractions were taken for colorimetric measurements.

(i) Invertase was assayed according to the method of Metzenberg (1962). A unit of activity was defined as the amount of enzyme that released I $\mu$ mole of glucose from sucrose/min at $37^{\circ}$. (ii) Trehalase activity was assayed by incubating I $\mathrm{ml}$ of reaction mixture containing enzyme solution, potassium phosphate buffer $(50 \mu$ mole, $\mathrm{pH} 6)$ and trehalose $(50 \mu$ mole) at $37^{\circ}$ for $60 \mathrm{~min}$. Incubation was terminated by heating in a boiling water bath for $2 \mathrm{~min}$. The glucose liberated was determined by the glucose oxidase method (Huggett \& Nixon, 1957). A unit of activity was defined as the amount of enzyme that hydrolysed I $\mu$ mole of trehalose to glucose $/ \mathrm{min}$ at $37^{\circ}$.

\section{RESULTS}

Treatment with chemical reagents. Buffers from $\mathrm{pH} 3 \cdot 0$ to $\mathrm{pH}$ io (about $0.05 \mathrm{M}$ ), Triton $\mathrm{X}-\mathrm{I} 00(\mathrm{I} \%, \mathrm{v} / \mathrm{v})$, EDTA $(0.5 \mathrm{mM}), \mathrm{KCl}(\mathrm{I} \mathrm{M})$, and $\beta$-mercaptoethanol ( $19 \mathrm{mM})$, in the final concentrations indicated in parentheses, caused a maximum of about $6 \%$ of the invertase activity in the wall fractions to appear in the supernatant fractions when compared to controls using water instead of the reagents. Therefore they failed to dissociate invertase from Neurospora wall fractions to any significant extent.

Treatment with hydrolytic enzymes. Snail-gut juice hydrolysed laminarin, pustulan, starch, and chitin very readily; cellulose and casein were hydrolysed to a smaller extent. With such a wide variety of hydrolytic activities, the snail-gut juice released $90 \%$ of the invertase and $93 \%$ of trehalase from Neurospora wall fractions over $24 \mathrm{~h}$; half of these enzymes were released after $0.25 \mathrm{~h}$ and $0.75 \mathrm{~h}$, respectively (Fig. I, 2). $\beta$-I,3-Glucanase, which specifically hydrolysed laminarin, released invertase and trehalase from Neurospora wall fractions more slowly but also more completely than snail-gut juice. After $24 \mathrm{~h}$ incubation, $94 \%$ of invertase and $96 \%$ of trehalase finally appeared in the supernatant fractions; half of each was released within $2 \mathrm{~h}$. Chitinase was rather specific in hydrolysing chitin, with slight hydrolytic activity towards laminarin evident only after $24 \mathrm{~h}$ of digestion. Chitinase digestion resulted in $79 \%$ of invertase and $63 \%$ of trehalase appearing in the supernatant fractions after $29 \mathrm{~h}$ of digestion. Trypsin digestion released only $19 \%$ of invertase into the supernatant, compared to almost $15 \%$ release in the control. The release of trehalase could not be assessed in this experiment since it was severely inactivated by trypsin. However, preliminary investigations showed a pattern of release similar to that obtained for invertase. Cellulase digestion seemed to release about $5 \%$ more of invertase and trehalase into the supernatant than was present in the controls after $8 \mathrm{~h}$ of incubation. However, after an extended period, up to $24 \mathrm{~h}$, the experimental results coincided with the control values, indicating that no significant amount of enzyme activity was released from the wall fraction. Hence, the effectiveness of the different hydrolytic enzymes in releasing invertase varied rather dramatically, and could be listed in the order of increasing potency as: cellulase, trypsin, chitinase, snail-gut juice and $\beta$-I,3-glucanase. The same order also applied to the release of trehalase. The rather high control values may be attributed to autolytic enzymes in walls as demonstrated in Neurospora by Mahadevan \& Mahadkar (1970) and in some other fungi by Mitchell \& Sabar(1966). 


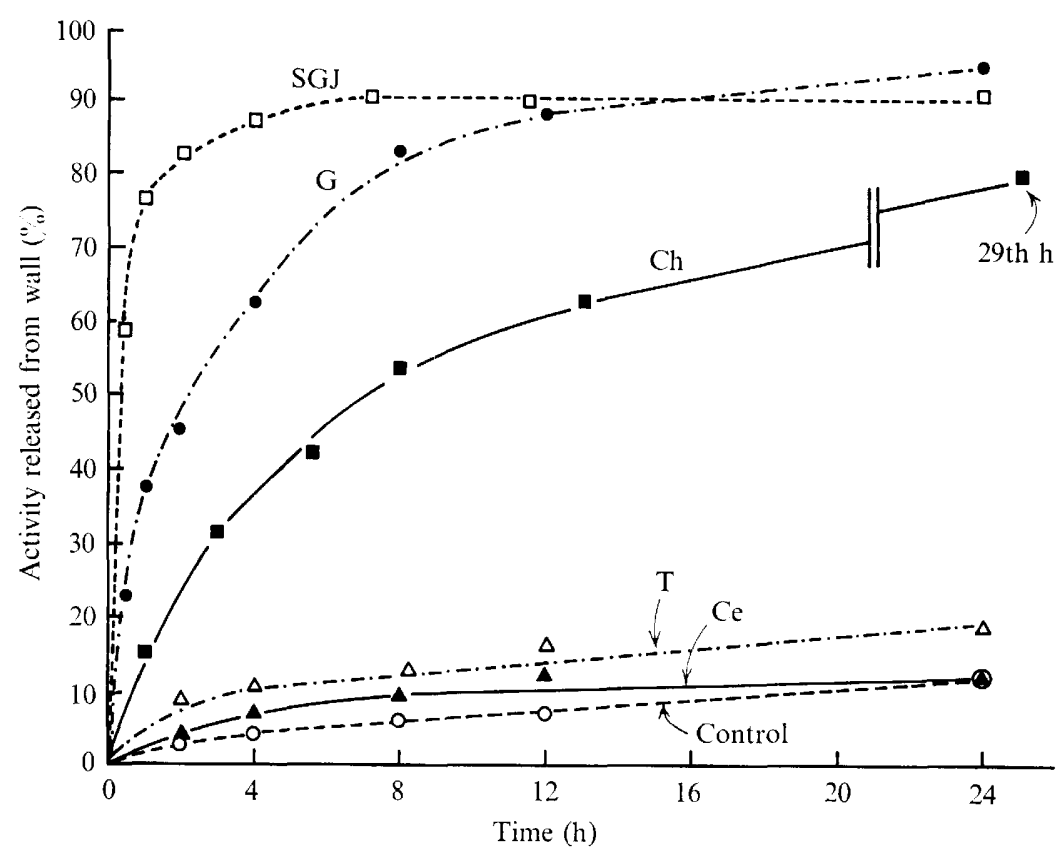

Fig. I. Release of invertase from Neurospora wall fractions by hydrolytic enzymes. Conditions of the experiment are described in the Methods.

$$
\% \text { activity released from wall }=\frac{\text { activity in supernatant }}{\text { activity in (supernatant }+ \text { wall residue) }} \times 100 .
$$

The percentage recovery of initial invertase activity after treatment with the hydrolytic enzyme is indicated in parentheses after the enzyme preparation used: SGJ (snail-gut juice) $(95 \%), \mathrm{G}(\beta-\mathrm{I}, 3-$ glucanase) $(92 \%)$, Ch (chitinase) $(84 \%)$, T (trypsin) $(87 \%$, Ce (cellulase) $(92 \%)$, Control (hydrolytic enzyme preparation replaced by 0.02 M-sodium acetate buffer, $\left.\mathrm{pH}_{5}^{\circ} \mathrm{0}\right)(85 \%)$.

Release of radioactivity from ${ }^{14} C$-labelled wall fractions by hydrolytic enzymes. The ability of the hydrolytic enzymes to release enzymes from the wall fraction did not seem to bear a direct relationship with their ability to digest ${ }^{14} \mathrm{C}$-labelled wall preparation (Table I). Trypsin did not release any significant amount of radioactivity although it was slightly more effective than cellulase in releasing the mural invertase. The release of about $10 \%$ of ${ }^{14} \mathrm{C}$-radioactivity by cellulase seemed to indicate the presence of cellulose-like glucan ( $\beta$-I,4-linked) in the Neurospora walls. A most marked disproportionality was observed in the chitinase digestion experiment. A mere $16 \%$ of ${ }^{14} \mathrm{C}$-radioactivity was released from the wall fraction although the amounts of invertase and trehalase released each reached about $70 \%$. However, $\beta$-I,3-glucanase, being more efficient than snail-gut juice in releasing the mural exoenzymes, also released coincidentally more ${ }^{14} \mathrm{C}$-radioactivity $(82 \%$, cf. $73 \%$ by snail-gut juice).

\section{DISCUSSION}

Several chemical reagents have been shown to alter the permeability or binding characteristics of bacterial and fungal walls. In Aspergillus oryzae the surface-bound $\alpha$-amylase was released at alkaline pH (Tonomura \& Tanabe, 1964). In the Gram-positive bacteria Staphylococcus aureus a portion of its penicillinase bound to the cell walls at specific ionic binding sites so that it could be instantaneously displaced by certain inorganic anions or polyanions 


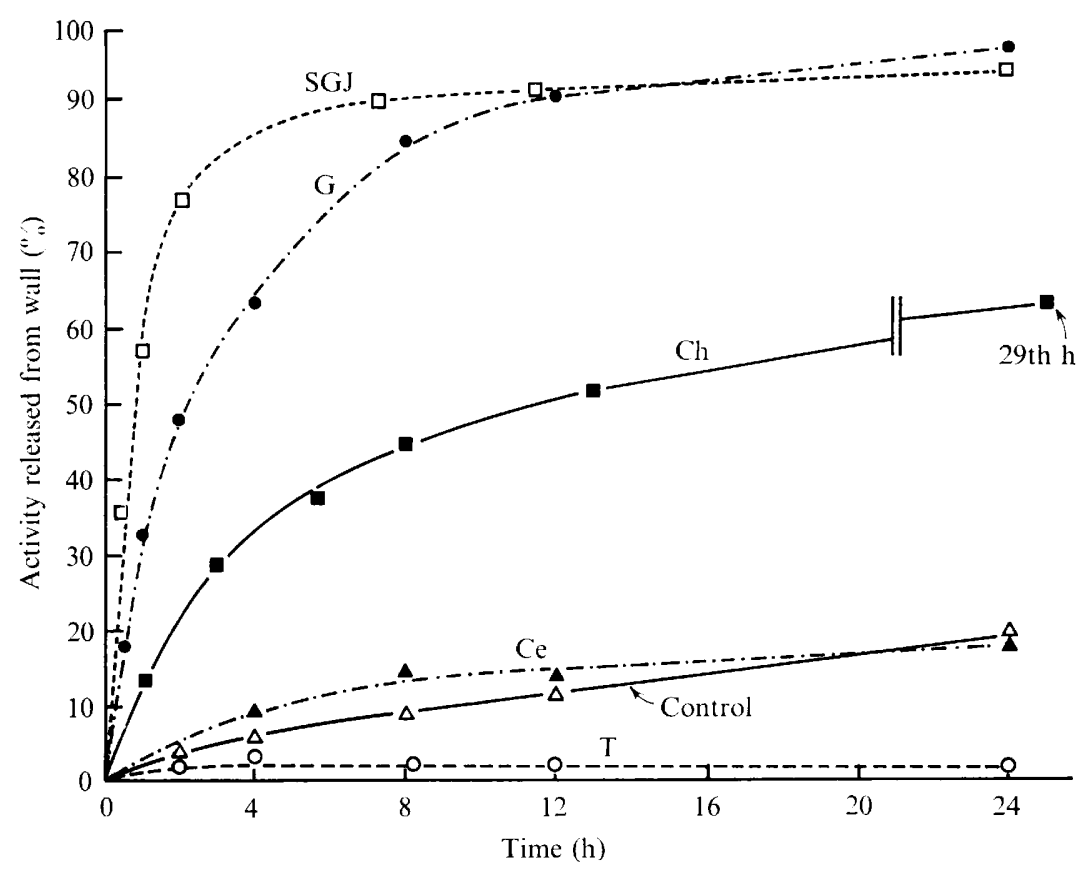

Fig. 2. Release of trehalase from Neurospora wall fractions by hydrolytic enzymes. The percentage recovery of initial trehalase activity after treatment with the hydrolytic enzymes is indicated in parenthesis after the enzyme preparation used (see Fig. I for a comparison of activities of invertase released): SGJ (snail-gut juice) $(60 \%), \mathrm{G}(\beta$-I,3-glucanase) $(78 \%)$, Ch (chitinase) $(8 \mathrm{I} \%)$, T (trypsin) $(47 \%)$, Ce (cellulase) $(99 \%)$, control $(84 \%)$.

(Coles \& Gross, 1967). EDTA is known to increase the permeability of Gram-negative bacterial cell envelopes (Costerton, 1970). Either $\mathrm{KCl}$ or mercaptoethanol could release acid phosphatase and invertase, two cell-bound exoenzymes, from Saccharomyces fragilis (Weimberg \& Orton, 1966; Kidby \& Davies, 1970). However, the chemical reagents used in our experiments, including buffers of $\mathrm{pH}_{3}$ to I0, $\mathrm{I} \%(\mathrm{v} / \mathrm{v})$ Triton X-Ioo, EDTA, $\mathrm{KCl}$ and $\beta$-mercaptoethanol, did not release any significant amount of the invertase from the wall

Table $\mathrm{I}$. Release of radioactivity from ${ }^{14} \mathrm{C}$-labelled wall fractions by hydrolytic enzymes

${ }^{14} \mathrm{C}$-Labelled wall fractions were incubated with the various hydrolytic enzymes for $24 \mathrm{~h} ; 100 \mu \mathrm{l}$ (sample A) and $200 \mu \mathrm{l}$ (sample B) of the incubation mixture were withdrawn. Control samples were similarly incubated with PBS substituting for hydrolytic enzymes. The difference of radioactivity in the wall residues between the control at $\mathrm{o}$ h and the enzyme digested samples after $24 \mathrm{~h}$ was taken to be the amount of ${ }^{14} \mathrm{C}$-radioactivity released from the wall fractions.

\begin{tabular}{lccc} 
Hydrolytic enzyme & $\begin{array}{c}\text { Residual radioactivity (d.p.m.) in } \\
\text { wall fraction }\end{array}$ & $\begin{array}{c}\text { Average \% of } \\
\text { radioactivity } \\
\text { released into } \\
\text { supernatant }\end{array}$ \\
\cline { 2 - 3 } Control (o h) & $\begin{array}{c}\text { Sample A } \\
\text { Trypsin }\end{array}$ & Sample B & $0 \cdot 0$ \\
Cellulase & 29,408 & 57,857 & $(0)$ \\
Chitinase & 27,162 & 57,540 & $9 \cdot 4$ \\
Snail-gut juice & 24,098 & 51,623 & $16 \cdot 6$ \\
$\beta$-1,3-Glucanase & 7,907 & $47,95 \mathrm{I}$ & $73 \cdot 4$ \\
Control (24 h) & 5,437 & 15,156 & $82 \cdot 3$ \\
& 28,445 & 9,723 & 3.8
\end{tabular}


fractions. Therefore this mural exoenzyme in Neurospora must be associated with the walls in ways different from the cases mentioned above.

Three conclusions can be drawn from the experiments on the release of invertase and trehalase from Neurospora wall fractions by various hydrolytic enzymes. First, invertase and trehalase are probably held in the walls in similar ways, and released only after covalent bonds of the wall components are broken. Secondly, these mural exoenzymes are not found exclusively associated with any single chemical component of the walls but the dissolution of glucan (by $\beta$-I,3-glucanase) or chitin (by chitinase) or protein (by trypsin) was effective in releasing a fraction of the exoenzymes. Thirdly, the amounts of enzymes released are not directly proportional to the amounts of ${ }^{14} \mathrm{C}$-labelled wall material that can be solubilized by the hydrolytic enzymes. These conclusions suggest three possibilities that may account for the mural association of invertase and trehalase in Neurospora. The first is that the exoenzymes are only physically confined within the matrix of the walls. If this is so, the various hydrolytic enzymes would cause a breakdown in the structural integrity of the wall which consequently becomes permeable to the exoenzymes. The second is that the exoenzymes are covalently bonded to one or more of the wall polymers. A third closely related possibility is that exoenzymes are bound to binding sites associated with one or more of the polymers of the wall, as seems possible for the $\alpha$-amylase of Aspergillus oryzae (Yabuki \& Fukui, 1970). Wrathal has (private communication, 197I) recently informed us that wall proteins of low molecular weight may be involved in the association of invertase with the walls of Neurospora. In the second and third possibilities, hydrolytic enzymes would not only disrupt the wall integrity but also 'dissect' out fragments of the wall polymers or portions of binding proteins which are linked to the enzyme molecules. These enzyme molecules, together with the attached wall fragments, would be able to diffuse through the partially degraded walls.

It is impossible to make a choice among these possibilities now but the following observations would favour the first one. During routine storage of purified wall fractions, a cycle of freeze-thawing was found to release up to $10 \%$ of the invertase activity into a supernatant fraction. This possibly indicates that mere mechanical force is sufficient to liberate some invertase from its association with the wall fraction. Hence, in the fraction of enzyme that is so released, no covalent bonds between the enzyme molecule and the wall could have been involved. Furthermore, if the liberated mural exoenzymes are still associated with wall fragments or binding proteins, their sizes would be larger than the same enzyme purified from the soluble fraction of the Neurospora homogenate. However, during disc-gel electrophoresis, invertase liberated from the wall fraction by enzymatic hydrolysis migrates to the same position as the invertase purified from Neurospora homogenate (unpublished data). Therefore, these two types of invertase are similar both in their charge and size characteristics - a property that can be best explained by the hypothesis that mural exoenzymes are only physically confined within the Neurospora wall.

The authors thank Dr C. F. Robinow, Dr D. B. Smith and Dr A. Wellman for helpful discussions during the course of this work. The assistance provided by a grant from the Medical Research Council of Canada is gratefully acknowledged. The paper formed part of a dissertation submitted by P.L.Y.C. in partial fulfilment of the requirements for the degree of Doctor of Philosophy, University of Western Ontario, London, Ontario, Canada. 


\section{REFERENCES}

BeAdle, G. W. \& TATUM, E. L. (I945). Neurospora. II. Methods of producing and detecting mutations concerned with nutritional requirements. American Journal of Botany 32, 678-686.

Berger, L. R. \& Reynolds, D. M. (1958). The chitinase system of a strain of Streptomyces griseus. Biochimica et biophysica acta 29, 522-534.

BurnetT, J. H. (1968). Fundamentals of Mycology, pp. I7-59. London: Edward Arnold.

Chung, P. L. Y. \& Trevithick, J. R. (1970). Biochemical and histochemical localization of invertase in Neurospora crassa during conidial germination and hyphal growth. Journal of Bacteriology ro2, 423-429.

Coles, N. W. \& Gross, R. (1967). Liberation of surface-located penicillinase from Staphylococcus aureus. Biochemical Journal 102, 742-747.

COSTERTon, J. W. (1970). The structure and function of the cell envelope of Gram-negative bacteria. Revue canadienne de biologie 29, 299-316.

De Terra, N. \& TAtum, E. L. (I963). A relationship between cell wall structure and colonial growth in Neurospora crassa. American Journal of Botany 50, 669-677.

Drysdale, R. B. \& Fling, M. (1965). Assay of proteolytic enzyme(s) from Neurospora crassa. Neurospora Newsletter 8, I4-I5.

EBerhart, B. M. (1961). Exogenous enzymes of Neurospora conidia and mycelia. Journal of Cellular and Comparative Physiology 58, I I-I 6 .

EBerhart, B. M. \& BECK, R. S. (1970). Localization of the $\beta$-glucosidases in Neurospora crassa. Journal of Bacteriology ror, 408-417.

Galsworthy, S. B. (1966). Biochemical Aspects of Temperature Sensitivity in Neurospora. Ph.D. Thesis, University of Wisconsin, Madison, Wisconsin.

Hill, E. P. \& Sussman, A. S. (1964). Development of trehalase and invertase activity in Neurospora. Journal of Bacteriology 88, I 556-1566.

Huggett, A. St G. \& Nixon, D. A. (1957). Enzymic determination of blood glucose. Biochemical Journal 66, I $2 P$.

KIDBy, D. K. \& Davies, R. (1970). Thiol induced release of invertase from cell walls of Saccharomyces fragilis. Biochimica et biophysica acta 201, 26I-266.

LAmpen, J. O. (1968). External enzymes of yeast: their nature and formation. Antonie van Leeuwenhoek 34, I-I 8.

Lampen, J. O., Neumann, N. P., Gascon, S. \& Montenecourt, B. S. (1967). Invertase biosynthesis and the yeast cell membrane. In Organisational Biosynthesis, pp. 363-372. Edited by H. J. Vogel, J. O. Lampen \& V. Bryson. New York: Academic Press.

McMurrough, I. \& Bartnicki-Garcia, S. (1970). Chitin synthesis in Mucor rouxii. Biochemical Journal II9, II P.

MahadeVAN, P. R. \& MahadKaR, U. R. (1970). Role of enzymes in growth and morphology of Neurospora crassa: cell-wall bound enzymes and their possible role in branching. Journal of Bacteriology Ior, 94I-947.

Mahadevan, P. R. \& Menon, C. P. S. (1968). Laminarinase of Neurospora crassa. I. Enzyme activity associated with conidia and conidial wall. Indian Journal of Biochemistry $5,6-8$.

MahadeVan, P. R. \& TATUM, E. L. (1965). Relationship of the major constituents of the Neurospora crassa cell wall to wild-type and colonial morphology. Journal of Bacteriology 90, 1073-I081.

MalAmy, M. H. \& HoReCKER, B. L. (1964). Release of alkaline phosphatase from cells of Escherichia coli upon lysozyme spheroplast formation. Biochemistry 3, I 889-1893.

MANDELS, G. R. (I953). Localization of carbohydrases at the surface of fungus spores by acid treatment. Experimental Cell Research 5, 48-55.

Matile, Ph. (1964). Die Funktion proteolytischer Enzyme bei der Proteinaufnahme durch Neurospora crassa. Naturwissenschaften 51, 489-490.

Merchant, D. J., Kahn, R. H. \& MurPhy, W. H. (1964). Handbook of Cell and Organ Culture, pp. I62I66. Minneapolis: Burgess Publishing Co.

MetzenberG, R. L. (1962). A gene affecting the repression of invertase and trehalase in Neurospora. Archives of Biochemistry and Biophysics 96, 468-474.

Mitchell, R. \& SABAR, N. (1966). Autolytic enzymes in fungal cell walls. Journal of General Microbiology 42, 39-42.

Pollock, M. R. (1962). Exoenzymes. In The Bacteria, vol. 4, pp. I21-178. Edited by I. C. Gunsalus \& R. Y, Stanier. New York: Academic Press. 
SCOTt, W. A. \& METZENBERG, R. L. (1970). Location of aryl sulfatase in conidia and young mycelia of Neurospora crassa. Journal of Bacteriology 104, 1254-1265.

TANAKA, H. \& PHAFF, H. J. (I965). Enzymatic hydrolysis of yeast cell walls. I. Isolation of wall-decomposing organisms and separation and purification of lytic enzymes. Journal of Bacteriology 89, 1570-1 580 .

TONOMURA, K. \& TANABE, O. (1964). Localization of cell-bound $\alpha$-amylase in Aspergillus oryzae demonstrated by fluorescent-antibody technique. Journal of Bacteriology 87, 226-227.

Trevithick, J. R. \& Metzenberg, R. L. (1964). The invertase isozyme formed by Neurospora protoplasts. Biochemical and Biophysical Research Communications 16, 319-325.

Trevithick, J. R. \& MetZeNBerg, R. L. (I966). Molecular sieving by Neurospora cell walls during secretion of invertase isozymes. Journal of Bacteriology 92, I010-101 5.

WeImberg, R. \& Orton, W. L. (1966). Elution of exocellular enzymes from Saccharomyces fragilis and Saccharomyces cerevisiae. Journal of Bacteriology 9I, I-I 3.

YABUKI, M. \& FUKUI, S. (I970). Presence of binding site for $\alpha$-amylase and of masking protein for this site on mycelial cell walls of Aspergillus oryzae. Journal of Bacteriology 104, I38-144. 